\title{
Cíle a indikátory pro environmentální vzdělávání, výchovu a osvětu v České republice
}

\author{
Lenka Broukalová, Miroslav Novák \\ Envigogika 2012/VII/1- Recenzované články/ Reviewed Papers \\ Publikováno/Published 31. 05. 2012 \\ DOI: http://dx.doi.org/10.14712/18023061.66
}

\section{Abstrakt:}

Nové cíle a indikátory pro environmentální vzdělávání, výchovu a osvětu v České republice stanovuje dokument vytvořený expertním týmem pracujícím při dnes už neexistujícím Odboru nástrojů politiky životního prostředí MŽP ČR.

Tento materiál byl zpracován v rámci projektu "Cíle a indikátory pro EVVO v České republice", který byl zadán Ministerstvem životního prostředí a realizován společností Integra Consulting, s.r.o.

Doporučení obsažená v tomto dokumentu byla připravena malým pracovním týmem ve složení: Lenka Broukalová, Václav Broukal, Jan Činčera, Petr Daniš, Tomáš Kažmierski, Jiří Kulich, Miroslav Lupač, Michal Medek a Miroslav Novák. Jana Dlouhá, Hana Korvasová, Jan Krajhanzl a Jozef Zetěk dodali cenné připomínky.

Příprava materiálu byla rovněž konzultována $\mathrm{v}$ rámci čtyř pracovních jednání s pracovní skupinou, která zahrnovala zástupce všech klíčových institucí a jejíž složení je uvedeno v př́loze tohoto materiálu. Proces př́pravy materiálu byl facilitován Jiřím Dusíkem a Martinem Smutným z Integra Consulting.

Dokument formuluje cíle v oblasti EVVO pro různé cílové skupiny anavrhuje vhodné postupy pro hodnocení plnění těchto cílů a účinnosti EVVO jako preventivního nástroje ochrany životního prostředí. z pohledu MŽP se jedná o cílezahrnující činnosti určené pro řadu cílových skupin (tedy nejen pro děti a mládež) bez ohledu na institucionální a formální postavení poskytovatele.

Pdf verze dokumentu je zde. 


\section{Klíčová slova:}

\section{Abstract:}

Key words: 


\section{Úvod}

\section{Účel dokumentu}

Tento dokument vznikl v roce 2011 jako výsledek projektu Ministerstva životního prostředí "Cíle a indikátory pro environmentální vzdělávání, výchovu a osvětu (EVVO) v České republice".

Účelem tohoto dokumentu je stanovit obecný cíl a rámcové cíle EVVO, která je integrální součástí právního rádu České republiky prostřednictvím ustanovení § 13 zákona č. 123/1998 Sb., o právu na informace o životním prostředí, ve znění změn provedených zákonem č. 132/2000 Sb., zákonem č. 6/2005 Sb., zákonem č. 413/2005 Sb. a zákonem č. $380 / 2009 \mathrm{Sb}$.

Dokument formuluje cíle v oblasti EVVO pro různé cílové skupiny a navrhuje vhodné postupy pro hodnocení plnění těchto cílů a účinnosti EVVO jako preventivního nástroje ochrany životního prostředí. z pohledu MŽP se jedná o cíle zahrnující činnosti určené pro řadu cílových skupin (tedy nejen pro děti a mládež) bez ohledu na institucionální a formální postavení poskytovatele.

Tento materiál má sloužit poskytovatelům EVVO, at' již jde o vzdělávací instituce, nestátní neziskové organizace, zájmová sdružení právnických osob i organizační složky veřejné správy a další organizace. Náměty obsažené $v$ tomto dokumentu by měly být využívány zejména jako základ pro posouzení zda a do jaké míry konkrétní EVVO programy, projekty a činnosti pro různé cílové skupiny přispívají k naplňování obecných a rámcových cílů EVVO, které Ize považovat za konsenzuální z hlediska státní správy a státní politiky ochrany životního prostředí, akademické obce věnující se environmentální výchově a zástupců stávajících poskytovatelů EVVO. Toto posouzení může sloužit pro sebehodnocení a jako pomůcka pro prrípravu dalších činností poskytovatelů EVVO.

Ministerstvu životního prostředí dokument poslouží pro hodnocení projektů v oblasti EVVO a jako podklad pro výkaznický systém a certifikaci poskytovatelů EVVO. Předpokládá se také, že cíle uvedené $v$ dokumentu budou návodem a referenčním rámcem, který využijí všechny subjekty zapojené do EVVO. Navržením způsobů hodnocení účinnosti EVVO pomocí indikátorů dochází ke splnění úkolu vyplývajícího z platného Akčního plánu ${ }^{1}$ Státního programu environmentálního vzdělávání, výchovy a osvěty².

\section{Charakter dokumentu}

EVVO je jedním z průřezových témat Rámcových vzdělávacích programů. Zařazování EVVO do výuky na školách má dlouholetou tradici a je výsledkem spolupráce MŠMT, MŽP, specializovaných pedagogických a vědeckovýzkumných institucí, škol a nestátních neziskových organizací. Dokument "Cíle a indikátory pro EVVO v České republice" vymezuje aktivity podporované EVVO $v$ gesci resortu Ministerstva životního prostředí a navrhuje způsoby ověření jejich účinnosti.

Dokument nenahrazuje platné metodické pokyny MŠMT, či metodický materiál "Doporučené očekávané výstupy, Metodická podpora pro výuku prưřezových témat v základních školách"3. Předkládaný text je však sestaven $s$ respektem $k$ těmto metodickým podkladům a zohledňuje i používaný pedagogický pojmový aparát. Proto by měly být navrhované př́klady aktivit pro dosažení rámcových cílů EVVO srozumitelné i pro

\footnotetext{
${ }^{1}$ Akční plán na léta 2010 - 2012 s výhledem do roku 2015 schválený vládou ČR usnesením č. 1302 ze dne 19. 10. 2009.

2 Státní program environmentálního vzdělávání, výchovy a osvěty v České republice schválený vládou ČR usnesením č. 1048/2000 ze dne 23. 10. 2000.

3 Pastorová M. et al.: Doporučené očekávané výstupy, Metodická podpora pro výuku průřezových témat v základních školách. Výzkumný ústav pedagogický v Praze, 2011
} 
pedagogy a mohly by se tak stát další inspirací pro jejich každodenní praxi. Dokument navazuje na všechny významné mezinárodní strategické dokumenty, které definují ekologickou výchovu ( $v$ širším slova smyslu) jako nástroj politiky ochrany životního prostředí a udržitelného rozvoje. Při jeho tvorbě byly tyto mezinárodní fundamenty EVVO respektovány.

Odborné zázemí pro vznik předkládaného dokumentu vytvořila Pracovní skupina pro cíle a indikátory EVVO, která postoupila jeho rozpracování užšímu týmu autorů. Tento užší tým tvořili zástupci zpracovatele, MŽP, akademické obce i organizací poskytujících EVVO všem cílovým skupinám.

Ministerstvo životního prostředí, zpracovatel, odborná pracovní skupina a autorský tým jsou upřímně přesvědčeni, že předkládaný dokument přispěje ke zkvalitnění procesu přípravy a vyhodnocování účinnosti environmentálního vzdělávání, výchovy a osvěty jako klíčového preventivního nástroje ochrany životního prostředí.

\section{Obecný cíl EVVo}

Obecným cílem EVVO v České republice je rozvoj kompetencí potřebných pro environmentálně odpovědné jednání tj. jednání, které je v dané situaci a daných možnostech co nejpříznivější pro současný i budoucí stav životního prostředí.

Environmentálně odpovědné jednání je chápáno jako odpovědné osobní, občanské a profesní jednání, týkající se zacházení s př́rodou a přírodními zdroji, spotřebitelského chování a aktivního ovlivňování svého okolí s využitím demokratických procesů a právních prostředků.

EVVO k takovému jednání připravuje a motivuje, samotné jednání je věcí svobodného rozhodnutí jednotlivce.

\section{Oblasti kompetencí a rámcové cíle EVVO} oblastech:

EVVO rozvíjí kompetence ${ }^{4}$ pro environmentálně odpovědné jednání v následujících

- Vztah k přírodě

- Vztah k místu

- Ekologické děje a zákonitosti

- Environmentální problémy a konflikty

- Připravenost jednat ve prospěch ŽP

\footnotetext{
${ }^{4}$ Kompetence jsou "komplexy znalostí, dovedností a postojů", resp. "soubory vědomostí, dovedností, schopností, postojů a hodnot důležitých pro osobní rozvoj a uplatnění každého jedince" (viz např. European Commission: Second Report on the activities of the Working Group on Basic Skills, Foreign Language Teaching and Entrepreneurship, 2003 a Rámcový vzdělávací program pro základní vzdělávání, VúP Praha, 2007, s. 14).
} 
Pro každou z výše uvedených pěti oblastí kompetencí je v následující tabulce stanoveno několik rámcových cílů, které společně vytvářejí komplex (soubor) žádoucích znalostí, dovedností, schopností, postojủ, a kterých by mělo být prostřednictvím EVVO dosahováno.

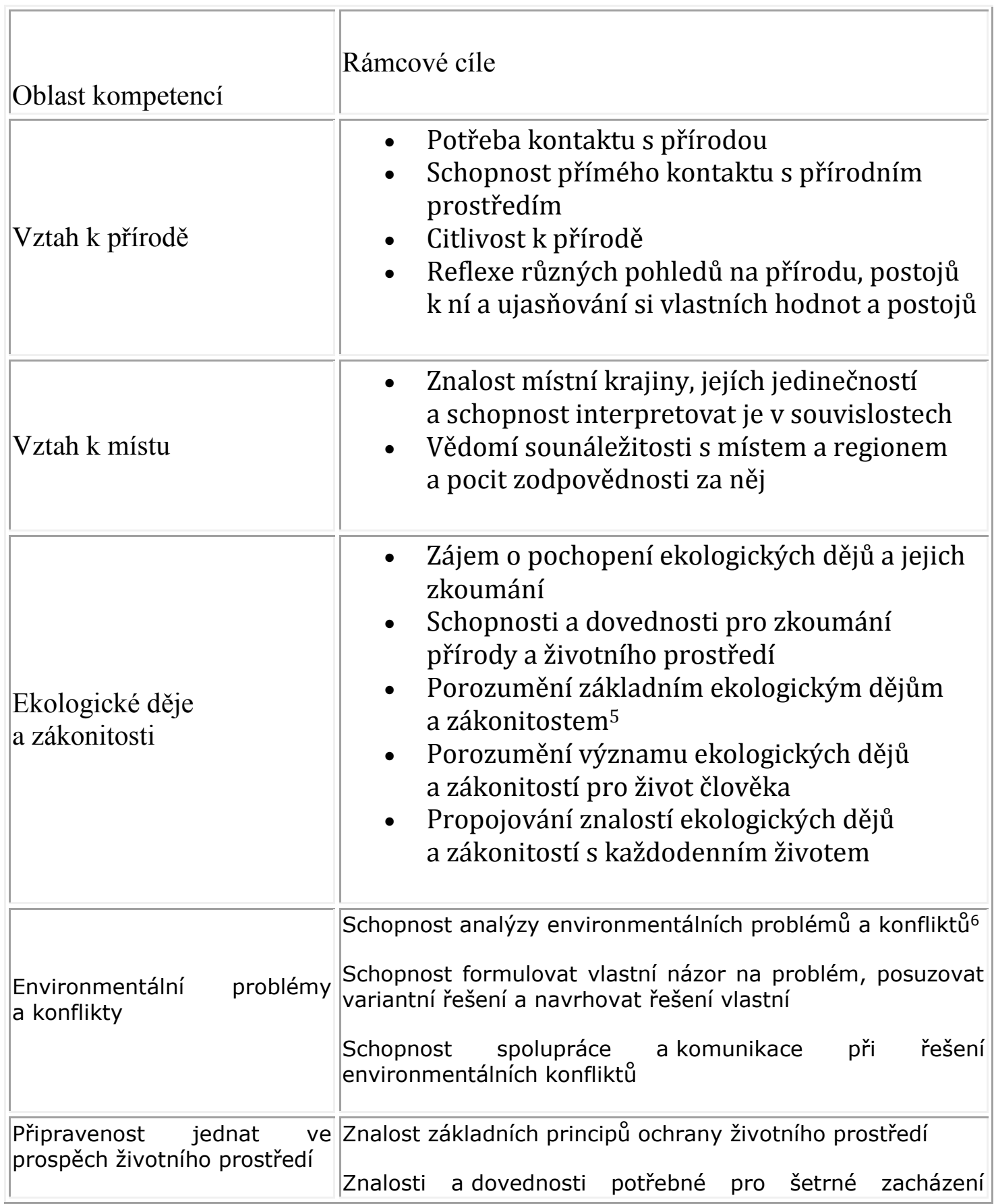

\footnotetext{
${ }^{5}$ Zákonitosti a vztahy mezi organismy navzájem a prostředím.

${ }^{6}$ Problém vzniká v situaci, kdy je ohrožena určitá složka životního prostředí. Konflikty vznikaji tehdy, pokud je více názorů na řešení problému.
} 
s přírodou a přírodními zdroji

Znalosti a dovednosti pro spotřebitelské chování

Znalosti a dovednosti pro aktivní ovlivňování svého okolí

Přesvědčení o vlastním vlivu na předcházení a řešení problémů životního prostředí

\section{Návrhy na využití rámcových cílů evvo a možnosti hodnocení EVvo}

V návaznosti na diskuse $v$ rámci Pracovní skupiny pro cíle EVVO Ize rámcové cíle potenciálně využít v systému EVVO v České republice při následujících aktivitách:

- Návrh a zavedení výkaznického systému;

- Ex-ante (vstupní) hodnocení projektů EVVO v rámci grantové či jiné podpory;

- Zavedení certifikace programů EVVO.

4.3.

Návrhy na využití rámcových cílů jsou podrobněji popsány v podkapitolách 4.1 až

Rámcové cíle mohou být také využity pro potřeby hodnocení EVVO na národní, regionální či školní úrovni (viz podkapitola 4.4). Tématu hodnocení jednotlivých programů a projektů EVVO je věnována podkapitola 4.5 (toto hodnocení je naopak vhodné provádět pŕímo vzhledem k vlastním cílừm hodnocených programů či projektů).

\section{Výkaznický systém}

Pro potřeby administrace a hodnocení činnosti organizací působících v oblasti EVVO se připravuje výkaznický systém. Ten bude zahrnovat rámcové cíle EVVO jako součást obecného popisu každého vykazovaného programu. To znamená, že každý program, který bude zařazen do výkaznického systému, zároveň uvede k naplňování kterého rámcového cíle (popř. cílů) přispívá. Výkaznický systém bude zahrnovat i další data (např. cíl programu, stručný popis, cílová skupiny, délka programu). Př́padné revizi, kontrole či hodnocení by pak podléhalo, zda je cíl konkrétního programu (příp. téma) v souladu s rámcovým cílem.

\section{EX-ante (Vstupní) Hodnocení}

Rámcových cílů EVVO bude využito pro posuzování žádostí o grant či podporu $v$ těchto finančních programech:

- Dotační program pro NNO

- Národní programy SFŽP - přílohy III.

- $\quad$ OPŽP - PO7

Ve formuláři žádosti o dotaci bude kladen dotaz i na př́slušný rámcový cíl EVVO. Předmětem hodnocení bude, zda předložený projekt dostatečně naplňuje rámcové cíle EVVO. Hodnocen tedy bude soulad cílů projektů s některými - relevantními - rámcovými cíli EVVO. 


\section{Certifikace}

V současné době (prosinec 2011) je připravován systém certifikace organizací poskytujících služby $v$ oblasti EVVO. Rámcové cíle budou využity jako vymezení EVVO pro potřeby tohoto certifikačního systému (kromě požadavků na fungování organizace je třeba vymezit i předmět činnosti organizace - tímto vymezením by měly být právě rámcové cíle).

\section{Možnosti hodnocení EVVO na národní, regionální či školní úrovni}

Lze předpokládat, že některé kompetence rozvíjené EVVO, jsou v některých segmentech populace zvládnuty na vyšší úrovni než $v$ jiných, a současně, že některé kompetence jsou plošně zvládnuty lépe, než jiné. Pro plánování EVVO na všech úrovních je důležité vědět, zda například kompetence související se vztahem k prírodě je důležitější rozvíjet ve městech, než na venkově, do jaké míry cítí obyvatelé určitého kraje sounáležitost se svým regionem, či zda jsou žáci středních škol schopni analyzovat environmentální konflikty ve svém okolí. Proměnné, související s rozvíjenými kompetencemi EVVO, je možné hodnotit na různých skupinách obyvatelstva. Typicky takové výzkumy ( $v$ zahraničí někdy označované jako výzkumy environmentální gramotnosti) probíhají na úrovni škol, regionů, na národní úrovni či jinak definovaných segmentech populace.

U takto zaměřených výzkumů zpravidla nejde jednoznačně přisuzovat efekt konkrétním programům, ale spíše určitému souhrnu programů a dalších opatření, působících v rámci daného kontextu.

Pomocí výzkumu tak můžeme například usuzovat na kvalitu environmentální výchovy na určité škole, současně si ale musíme být vědomi kontextu, ve kterém škola pracuje (škola může například pưsobit v sociálně vyloučené oblasti, může mít velké procento dětí se specifickými poruchami učení, může mít komplikovaný přístup k přírodě atd.).

Obdobně můžeme nepř́mo usuzovat na kvalitu systému EVVO v daném regionu; současně je třeba zjištěná data opět dávat do kontextu s dalšími faktory (kvalita životního prostředí v regionu, míra nezaměstnanosti, dostupnost nabídky programů EVVO atd.).

Výstupem zpravidla bývá recenzovaná studie, ve které jsou naměřené hodnoty porovnávány s výsledky jiných studií a diskutovány z hlediska limitů použité metodologie i kontextuálních faktorů. Na jejím základě pak mohou být přijata opatření ke zkvalitnění environmentální výchovy $v$ dané oblasti, např. formou podpory programů zaměřených na rámcový cíl EVVO, který podle výzkumu není adekvátně naplňován, nebo zaměřením se na segment populace s nízkou hladinou zvládnutí sledované kompetence.

\section{Možnosti hodnocení jednotlivých programů a projektů EVVO}

Cílem evaluace programů je zpravidla přispět k porozumění tomu, jak program funguje, a pomoci ho dále zkvalitnit (formativní evaluace), př́padně vyhodnotit, zda má smysl v realizaci a podpoře určitého programu dále pokračovat (sumativní evaluace). Takové hodnocení Ize provádět formou interní nebo externí evaluace. Interní evaluace předpokládá, že hodnocení bude zajištovat organizace, která nabízí hodnocený program. Tento postup je vhodný zejména u kratších programů. Externí evaluace znamená, že organizace najme jako hodnotitele subjekt, který s ní není přímo spojený. Externí evaluace má výhodu vyšší objektivity, interní evaluace zase komplexnějšího vhledu do programu. At' již je zvolena jakákoliv forma, doporučuje se, aby evaluátor a zástupci hodnocené organizace vytvořili společný tým a v něm plánovali postup evaluace.

V první fázi evaluátor analyzuje program a zkoumá, zda má předpoklady naplnit své cíle. Součástí mưže být i analýza potřeb - ujasnění, zda jsou cíle programu relevantní pro danou cílovou skupinu. $v$ další fázi evaluační tým formuluje evaluační otázky. Ty se nejčastěji vztahují k výstupům či dopadům programu na znalosti, dovednosti, postoje, přesvědčení, hodnoty či chování cílové skupiny. Druhou možností je zaměřit se na to, 
jakým způsobem účastníci program prožívají, co pro ně program znamená, co si během něj uvědomili nového. Třetím možným směrem je zaměřit se na vyhodnocení poměru mezi př́nosy a náklady programu.

Podle zvolených otázek evaluace využívá kvantitativní, kvalitativní či smíšený design. Kvantitativní evaluace zpravidla predpokládá statistickou analýzu získaných dat. Kvalitativní evaluace používá principy sémantické analýzy, často vychází z principů tzv. zakotvené teorie. Smíšený design kombinuje oba př́stupy. Přestože je metodologicky nejnáročnější, bývá při evaluacích často používán.

Výstupem evaluace by mělo být zodpovězení evaluačních otázek, upozornění na limity výzkumu a návrh doporučení na další zkvalitňování programu (formativní evaluace), případně doporučení k rozhodování o další podpoře programu (sumativní evaluace). v českém kontextu mají smysl zejména formativní evaluace, které pomáhají zkvalitňovat nabídku a podporují realizátory v odborném růstu.

\section{Vysvětlující komentář $\mathbf{k}$ rámcovým cílům a orientační příklady možností ověření jejich naplňování}

Vztah k př́rodě

\begin{tabular}{|c|c|c|}
\hline Rámcový cíl & $\begin{array}{l}\text { Vysvětlující komentár (je nutno } \\
\text { brát jako pouze ilustrativní } \\
\text { a indikativní výklad) }\end{array}$ & $\begin{array}{l}\text { Orientační příklady možností } \\
\text { ověření, popř. indikátorů (co je } \\
\text { např́klad možné vyhodnocovat } \\
\text { a jakým nástrojem) }\end{array}$ \\
\hline $\begin{array}{l}\text { Potřeba } \\
\text { s přírodou }\end{array}$ & $\begin{array}{l}\text { Zájem vyhledávat kontakt } \\
\text { s prírodou a trávit v ní volný čas. }\end{array}$ & $\begin{array}{l}\text { Množství volného času } \\
\text { tráveného v prírodě (dotazník, } \\
\text { rozhovor, portfolio). } \\
\text { Analýza } \\
\text { o subjektivním prožívání vovědí } \\
\text { k prírodě (rozhovor, volný text, } \\
\text { obrazová reflexe). }\end{array}$ \\
\hline $\begin{array}{l}\text { Schopnost přímého } \\
\text { kontaktu s prírodním } \\
\text { prostředím }\end{array}$ & 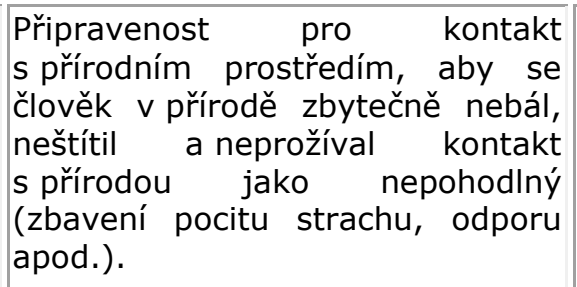 & $\begin{array}{l}\text { Chování jedince či skupiny } \\
\text { v přírodě } \quad \text { (strukturované } \\
\text { pozorování). } \\
\text { Znalost principů pobytu } \\
\text { v prírodě (dotazník). }\end{array}$ \\
\hline Citlivost k př́rodě & $\begin{array}{l}\text { Všímavost vưči dění v přírodě. } \\
\text { Schopnost vyjádřit vlastní prožitek } \\
\text { př́rody } \quad-\quad \text { slovní, písemné, }\end{array}$ & $\begin{array}{l}\text { Reflektivní zachycení prožitku } \\
\text { prírody - např. jak se v něm } \\
\text { objevuje př́roda, co z přirody, } \\
\text { v jakém kontextu (rozhovor, }\end{array}$ \\
\hline
\end{tabular}




\begin{tabular}{|c|c|c|}
\hline & 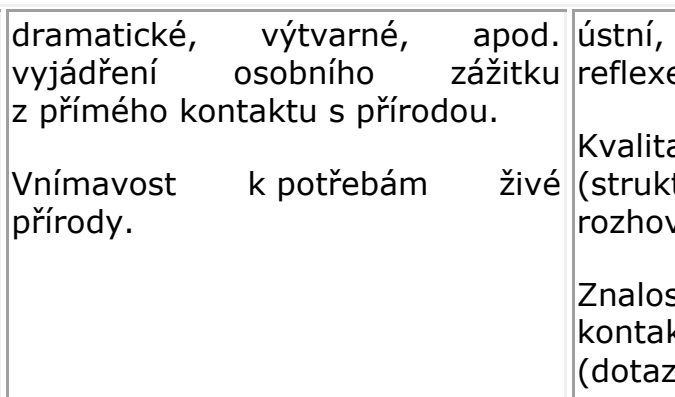 & $\begin{array}{l}\text { písemná či obrazová } \\
\text { e) } \\
\text { péče o živý organismus } \\
\text { turované pozorování, } \\
\text { ory). } \\
\text { ti a dovednosti pro } \\
\text { tt s živými tvory } \\
\text { ník). }\end{array}$ \\
\hline $\begin{array}{lr}\text { Reflexe } & \text { různých } \\
\text { pohledů na } & \text { přírodu, } \\
\text { postojů } & \mathrm{k} \mathrm{ní} \\
\text { a ujasňování } & \text { si } \\
\text { vlastních } & \text { hodnot } \\
\text { a postojů } & \end{array}$ & 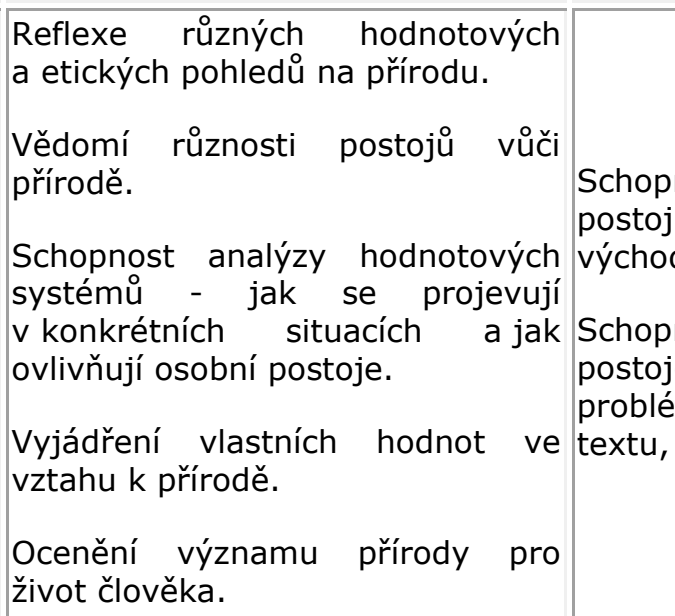 & $\begin{array}{l}\text { nost přiřadit k určitému } \\
\text { i možné hodnotové } \\
\text { disko (test, rozhovor) } \\
\text { nost vyjádřit vlastní } \\
\text { e a hodnoty k danému } \\
\text { mu (analýza volného } \\
\text { eseje, rozhovor). }\end{array}$ \\
\hline \multicolumn{3}{|l|}{ Vztah k místu } \\
\hline Rámcový cíl & $\begin{array}{l}\text { Vysvětlující komentář (je nutno brát } \\
\text { jako pouze ilustrativní a indikativní } \\
\text { výklad) }\end{array}$ & \begin{tabular}{lr} 
Orientační & \multicolumn{2}{c}{ příklady } \\
možností ověření, popř. \\
indikátorů & (co $r$ je \\
např́klad & možné \\
vyhodnocovat & a jakým \\
nástrojem) &
\end{tabular} \\
\hline $\begin{array}{l}\text { Znalost místa, jeho } \\
\text { jedinečnosti } \\
\text { a schopnost } \\
\text { interpretovat } \\
\text { v souvislostech jej }\end{array}$ & $\begin{array}{l}\text { Schopnost popsat čím je určité místo } \\
\text { jedinečné, jak v něm funguje propojení } \\
\text { společnost-příroda, jak se místo } \\
\text { proměňovalo v závislosti na rưzných } \\
\text { faktorech, jaké jsou citlivé složky } \\
\text { prostředí v místě, jak se místo odráží } \\
\text { v kultuře, příbězích apod. }\end{array}$ & $\begin{array}{l}\text { Znalost významných míst } \\
\text { v krajině, místních } \\
\text { př́běhů (test, portfolio, } \\
\text { rozhovor). } \\
\text { Úroveň percepce (místní) } \\
\text { krajiny (mentální mapy, } \\
\text { rozhovor, esej). }\end{array}$ \\
\hline $\begin{array}{l}\text { Vědomí sounáležitosti } \\
\text { s místem a regionem } \\
\text { a pocit zodpovědnosti } \\
\text { za něj }\end{array}$ & $\begin{array}{l}\text { Schopnost popsat, proč je pro mě dané } \\
\text { místo dưležité, jaké lokality v něm mám } \\
\text { rád, co se mi v něm líbí/nelíbí, co pro } \\
\text { místo můžu udělat, jaké vnímám } \\
\text { problémy místa. }\end{array}$ & $\begin{array}{l}\text { Ochota trávit v lokalitě } \\
\text { volný čas (dotazník) } \\
\text { Vztah k místu (dotazník, } \\
\text { rozhovor, esej, volný }\end{array}$ \\
\hline
\end{tabular}

\footnotetext{
${ }^{7}$ Analýza může vycházet z předem určených kategorií, nebo může být "otevřená" tématům, které se ve skupině objeví.
} 


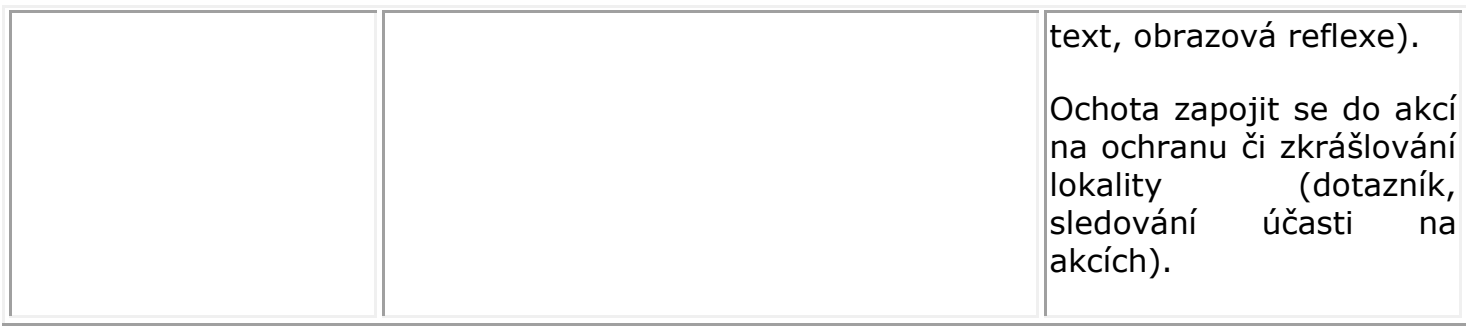

Ekologické děje a zákonitosti

\begin{tabular}{|c|c|c|}
\hline Rámcový cíl & $\begin{array}{l}\text { Vysvětlující komentář (je nutno brát jako } \\
\text { pouze ilustrativní a indikativní výklad) }\end{array}$ & $\begin{array}{lr}\text { Orientační } & \text { př́íklady } \\
\text { možností ověrení, popř. } \\
\text { indikátorůr } & \text { (co je je } \\
\text { např́klad } & \text { možné } \\
\text { vyhodnocovat } & \text { a jakým } \\
\text { nástrojem) } & \end{array}$ \\
\hline \multirow{4}{*}{$\begin{array}{l}\text { Zájem o pochopení } \\
\text { ekologických dějů } \\
\text { a jejich zkoumání }\end{array}$} & $\begin{array}{l}\text { Vědomí potřebnosti vědeckého zkoumání } \\
\text { ekologických jevů. }\end{array}$ & $\begin{array}{ll}\text { Zájem } & \text { o odbornou } \\
\text { ekologickou } & \text { literaturu } \\
\text { (počet } & \text { výpưjček } \\
\text { odborných } & \text { publikací } \\
\text { z knihovny, dotazník). }\end{array}$ \\
\hline & $\begin{array}{l}\text { Uvědomění si } \quad \text { nejistot } \quad v \text { poznání } \\
\text { ekologických dějů }\end{array}$ & $\begin{array}{lr}\begin{array}{ll}\text { Zájem } & \text { o školní } \\
\text { výzkumné } & \text { projekty } \\
\text { (počet } & \text { žáků }\end{array}\end{array}$ \\
\hline & \multirow{2}{*}{$\begin{array}{l}\text { Vlastní zkušenost se zkoumáním } \\
\text { ekologických dějư a její reflexe. }\end{array}$} & \multirow{2}{*}{$\begin{array}{l}\text { v projektech, dotazník). } \\
\text { Atraktivita vědecké } \\
\text { dráhy v oblasti ekologie } \\
\text { (dotazník, rozhovor, } \\
\text { ohnisková skupina). }\end{array}$} \\
\hline & & \\
\hline $\begin{array}{lr}\text { Schopnosti } & \\
\text { a dovednosti } & \text { pro } \\
\text { zkoumání } & \text { přírody } \\
\text { a životního prostředí }\end{array}$ & $\begin{array}{l}\text { - Schopnost kritické analýzy informací } \\
\text { o životním prostředí, formulování } \\
\text { otázek, navrhování postupu výzkumu, } \\
\text { sběr dat, vyhodnocení a interpretace } \\
\text { získaných údajů. }\end{array}$ & $\begin{array}{l}\text { Schopnost } \quad \text { zvládnout } \\
\text { jednotlivé } r \text { fáze } \\
\text { vědeckéhor postupu } \\
\text { (portfolio, pozorování, } \\
\text { dovednostní test). }\end{array}$ \\
\hline $\begin{array}{l}\text { Porozumění základním } \\
\text { ekologickým dějům } \\
\text { a zákonitostem8 }\end{array}$ & $\begin{array}{l}\text { Osvojení základních } \\
\text { (ekosystém, biodiverzita, ekologínů } \\
\text { stabilita, apod.), pochopení základních } \\
\text { procesù (toků energie, vodního cyklu, } \\
\text { koloběhu látek, vztahù mezi organismy } \\
\text { a jejich prostř́edím), vývoji populací } \\
\text { a společenstev, apod. }\end{array}$ & 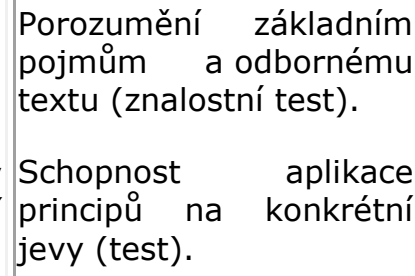 \\
\hline & & \\
\hline
\end{tabular}

8 Zákonitosti a vztahy mezi organismy navzájem a prostředím. 


\begin{tabular}{|c|c|c|}
\hline $\begin{array}{l}\text { ekologických dějů } \\
\text { a zákonitostí pro život } \\
\text { člověka }\end{array}$ & $\begin{array}{l}\text { ekologických dějů a zákonitostí pro život } \\
\text { člověka (služeb a funkcí ekosystémů). } \\
\text { Porozumění závislosti lidské společnosti } \\
\text { na přírodním prostředí. }\end{array}$ & $\begin{array}{l}\text { mezi člověkem } \\
\text { a přírodou (esej, volný } \\
\text { text, znalostní test, } \\
\text { rozhovor). }\end{array}$ \\
\hline $\begin{array}{lr}\text { Propojování } & \text { znalostí } \\
\text { ekologických } & \text { dějů } \\
\text { a zákonitostí } & \\
\text { s každodenním } \\
\text { životem }\end{array}$ & $\begin{array}{l}\text { Schopnost aplikovat ekologické děje } \\
\begin{array}{l}\text { a zákonitosti na prímou životní } \\
\text { zkušenost. }\end{array}\end{array}$ & 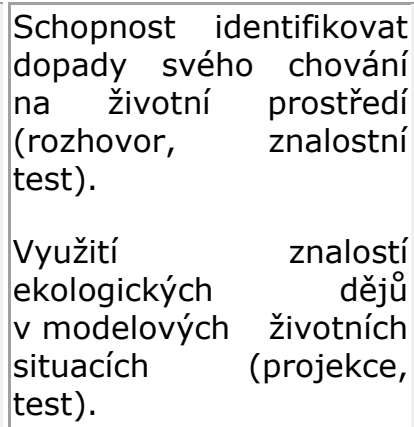 \\
\hline
\end{tabular}

\section{Environmentální problémy a konflikty}

\begin{tabular}{|c|c|c|}
\hline Rámcový cíl & \begin{tabular}{|l} 
Vysvětlující komentář (je \\
nutno brát jako pouze \\
ilustrativní \\
výklad)
\end{tabular} & $\begin{array}{l}\text { Orientační příklady možností } \\
\text { ověření, popř. indikátorů } \\
\text { (co je např́klad možné } \\
\text { vyhodnocovat a jakým nástrojem) }\end{array}$ \\
\hline $\begin{array}{l}\text { Schopnost analýzy } \\
\text { environmentálních } \\
\text { problémů a konfliktůa }\end{array}$ & 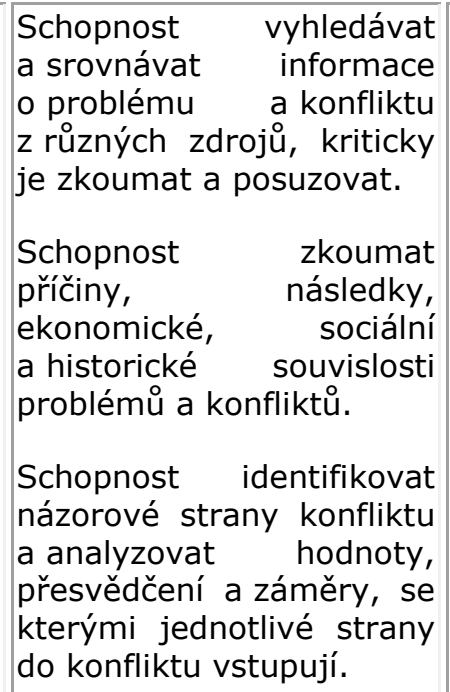 & 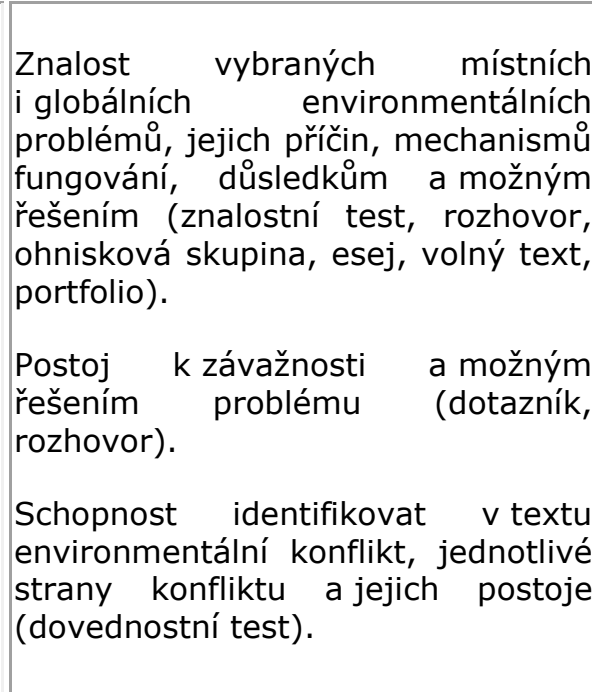 \\
\hline $\begin{array}{l}\text { Schopnost formulovat } \\
\text { vlastní názor na problém, } \\
\text { posuzovat } \quad \text { variantní } \\
\text { řešení a navrhovat řešení } \\
\text { vlastní }\end{array}$ & 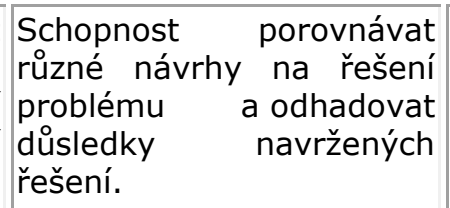 & $\begin{array}{l}\text { Schopnost zvážit jednotlivé varianty } \\
\text { a navrhnout alternativní řešení } \\
\text { environmentálního konfliktu (esej, } \\
\text { rozhovor, ohnisková skupina, } \\
\text { hodnocení žákovských projektů). }\end{array}$ \\
\hline
\end{tabular}

\footnotetext{
${ }^{9}$ Problém vzniká v situaci, kdy je ohrožena určitá složka životního prostředí. Konflikty vznikají tehdy, pokud je více názorů na řešení problému.
} 


\begin{tabular}{|c|c|c|}
\hline & $\begin{array}{l}\text { Schopnost posoudit } \\
\text { přijatelnost navrženého } \\
\text { řešení pro různé názorové } \\
\text { strany konfliktu. }\end{array}$ & \\
\hline $\begin{array}{l}\text { Schopnost spolupráce } \\
\text { a komunikace při řešení } \\
\text { environmentálních } \\
\text { konfliktů }\end{array}$ & 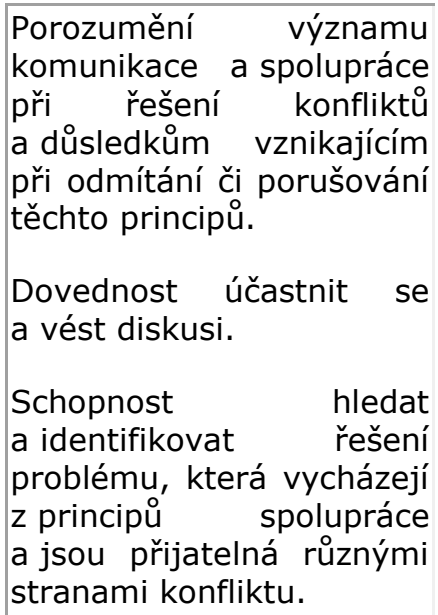 & $\begin{array}{l}\text { Schopnost vést dialog, metody } \\
\text { rozhodování, ochota zapojit se do } \\
\text { diskuse a řešení (strukturované } \\
\text { pozorování, rozhovory). }\end{array}$ \\
\hline
\end{tabular}

Připravenost jednat ve prospěch životního prostředí

\begin{tabular}{|c|c|c|}
\hline Rámcový cíl & $\begin{array}{l}\text { Vysvětlující komentář (je nutno brát } \\
\text { jako pouze ilustrativní a indikativní } \\
\text { výklad) }\end{array}$ & $\begin{array}{l}\text { Orientační př́klady možností } \\
\text { ověření, popř. indikátorù (co } \\
\text { je např́klad } \\
\begin{array}{l}\text { vyhodnocovat } \\
\text { nástrojem) }\end{array}\end{array}$ \\
\hline $\begin{array}{l}\text { Znalost } \\
\text { základních } \\
\text { principư ochrany } \\
\text { Životního } \\
\text { prostředí }\end{array}$ & $\begin{array}{l}\text { Porozumění principům ochrany } \\
\text { životního prostředí a udržitelného } \\
\text { rozvoje - např. princip prevence, } \\
\text { princip únosného zatížení prostředí, } \\
\text { princip předběžné opatrnosti, princip } \\
\text { odpovědnosti pưvodce (znečišt́ovatel } \\
\text { platí), princip informovanosti a účasti } \\
\text { veřejnosti, princip zohlednění vztahu } \\
\text { "lokální - globální" (mysli globálně, } \\
\text { jednej lokálně). }\end{array}$ & 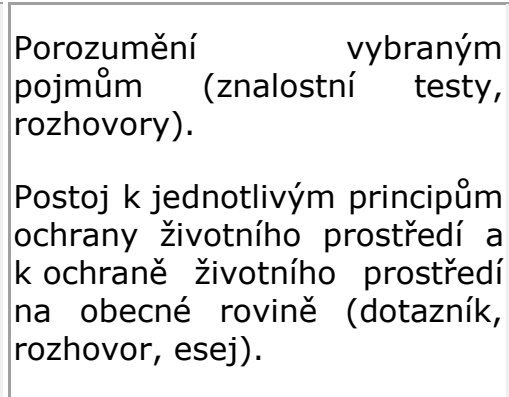 \\
\hline $\begin{array}{l}\text { Znalosti } \\
\text { a dovednosti } \\
\text { potřebné pro } \\
\text { šetrné zacházení } \\
\text { s přírodou } \\
\text { a př́rodními zdroji }\end{array}$ & $\begin{array}{l}\text { Osvojení dovedností pro ohleduplné } \\
\text { jednání vưči přírodě, pro šetrný pobyt } \\
\text { v přírodě, šetrné využívání přírody } \\
\text { a nakládání s jejími součástmi. } \\
\text { Porozumění } \\
\text { a technologickým řešením, která jsou } \\
\text { šetrná k životnímu prostředí zejm. } \\
\text { v oblastech snižování znečištění a úspor } \\
\text { přírodních zdrojů, a schopnost jejich } \\
\text { použití - např. tř́dění odpadů, využití } \\
\text { druhotných surovin a obnovitelných } \\
\text { zdrojů energie, šetření vodou } \\
\text { a elektřinou, výběr zpưsobu dopravy, }\end{array}$ & 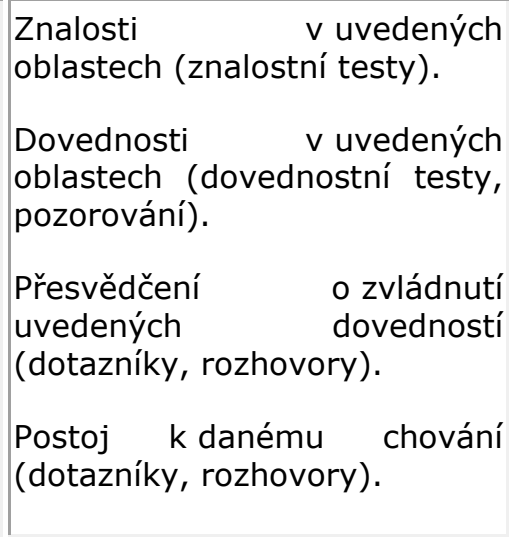 \\
\hline
\end{tabular}




\begin{tabular}{|c|c|c|}
\hline & $\begin{array}{l}\text { zavádění systémů environmentálního } \\
\text { managementu. }\end{array}$ & $\begin{array}{l}\text { Odhodlání k danému chováni } \\
\text { (dotazník, rozhovor). } \\
\text { Proenvironmentální chováni } \\
\text { v dané oblasti (dotazník, } \\
\text { pozorování, rozhovor). }\end{array}$ \\
\hline $\begin{array}{l}\text { Znalosti } \\
\text { a dovednosti pro } \\
\text { spotřebitelské } \\
\text { chování }\end{array}$ & $\begin{array}{l}\text { Znalost environmentálního značení } \\
\text { (ekoznačky - např́. EŠV, FSC, Bio), } \\
\text { schopnost posouzení "ekologické stopy" } \\
\text { výrobku (přepravní vzdálenost, } \\
\text { spotřeba energie, recyklovatelnost } \\
\text { apod.), etického a sociálního rozměru } \\
\text { (např. fair trade). } \\
\begin{array}{l}\text { Schopnost posuzovat a předvídat } \\
\text { dopady vlastního jednání na životní } \\
\text { prostředí. }\end{array}\end{array}$ & 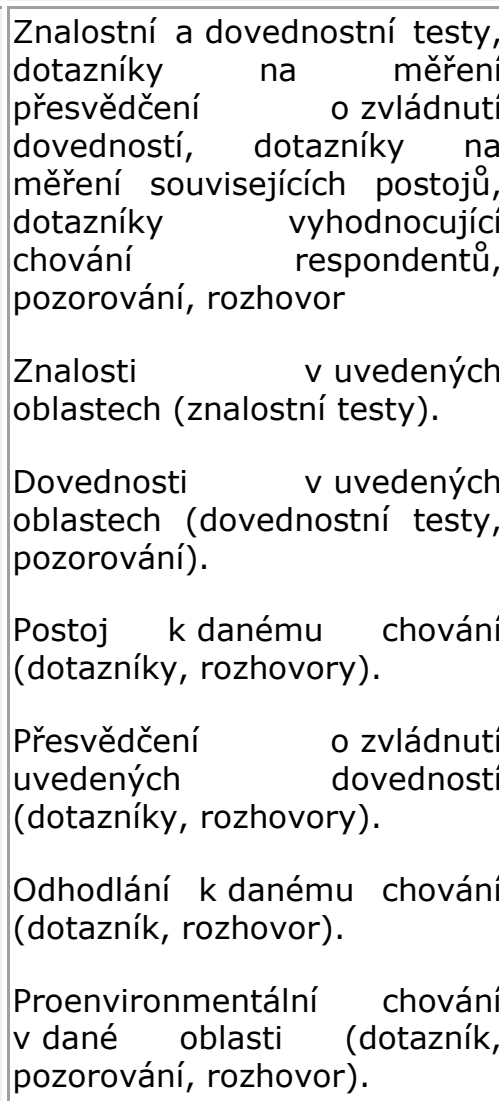 \\
\hline $\begin{array}{l}\text { Znalosti } \\
\text { a dovednosti pro } \\
\text { aktivní } \\
\text { ovlivňování svého } \\
\text { okolí }\end{array}$ & $\begin{array}{l}\text { Orientace v legislativním rámci ve } \\
\text { vztahu k životnímu prostředí a účasti } \\
\text { občanů na rozhodoování (znalost práv } \\
\text { a povinností, např. právo na príznivé } \\
\text { životní prostředí, právo na informace, } \\
\text { právo na účast v rozhodování) } \\
\text { a schopnost využití demokratických } \\
\text { nástrojů na prosazování ekologicky } \\
\text { příznivých rešení (např. zapojení do } \\
\text { územního plánování, do procesu EIA, } \\
\text { do správních řízení, využití petice, } \\
\text { diskuse s volenými zástupci nebo } \\
\text { kandidáty do veřejných funkcí apod.). }\end{array}$ & 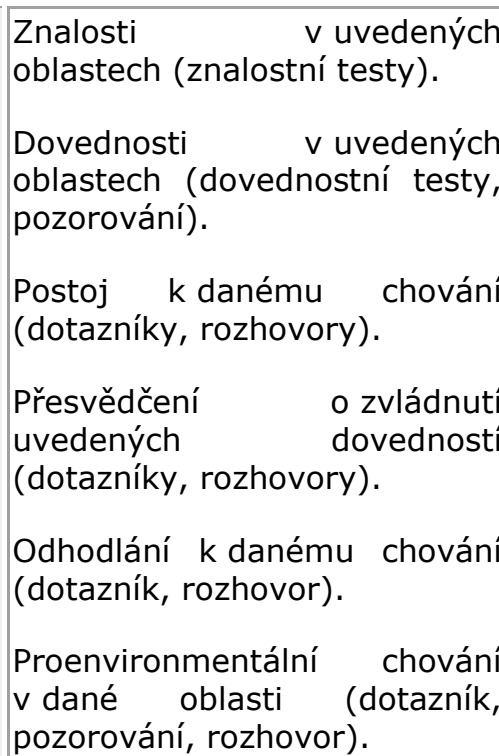 \\
\hline
\end{tabular}


Přesvědčení Motivace a ochota k zapojení do řešení Ohnisko kontroly (dotazník, o vlastním vlivu problémů životního prostředí.

na předcházení

a řešení problémů Vědomí / přesvědčení, že svým Ochota zapojit se do životního jednáním mohu pozitivně ovlivnit stav konkrétních akcí na ochranu prostředí Životního prostředí. životního prostředí (dotazník).

Příloha: Složení pracovní skupiny k projektu cíle a indikátory pro environmentální vzdělávání, výchovu a osvětu v české republice

\begin{tabular}{|c|c|}
\hline Jméno a příjmení & Organizace \\
\hline Jan Činčera & TUL \\
\hline Jozef Zetěk & Chaloupky \\
\hline Lenka Broukalová & SSEV Pavučina \\
\hline Vašek Broukal & SSEV Pavučina \\
\hline Jiří Bureš & SEV Paleta \\
\hline Petr Daniš & Sdružení TEREZA \\
\hline Petra Šimonová & Sdružení TEREZA \\
\hline Hana Korvasová & LIPKA \\
\hline Pavel Ehrlich & CENIA \\
\hline Mirek Lupač & Agentura KONIKLEC \\
\hline Jakub Halaš & Muzeum Ř́íčany \\
\hline Jiří Kulich & SEVER \\
\hline Zorka Husová & NÚOV \\
\hline Milada Švecová & Přf UK \\
\hline Michal Bartoš & Sluňákov \\
\hline Tereza Vláčilová & ČSOP \\
\hline Štěpán Jiří & ZL Kraj \\
\hline Jana Dlouhá & COŽP \\
\hline
\end{tabular}




\begin{tabular}{|l|l|}
\hline Jiří Dusík & Integra Consulting \\
\hline Martin Smutný & Integra Consulting \\
\hline Tomáš Kažmierski & MŽP \\
\hline Jitka Burianová & MŽP \\
\hline Miroslav Novák & MŽP \\
\hline Pavlína Slavíková & CENIA \\
\hline Zuzana Dvořáková & NÚOV \\
\hline Michal Medek & MU Brno \\
\hline
\end{tabular}

Lenka Broukalová: broukalova@pavucina-sev.cz, tel: +420234 621386

Miroslav Novák: miroslav.novak@mzp.cz, tel: +420-2-6712-2272 
Časopis Envigogika vydává Centrum pro otázky životního prostředí UK. Vývoj časopisu je podpořen projektem OP VK Mezioborová sít udržitelného rozvoje.

Více najdete na internetových stránkách projektu http://mosur.czp.cuni.cz
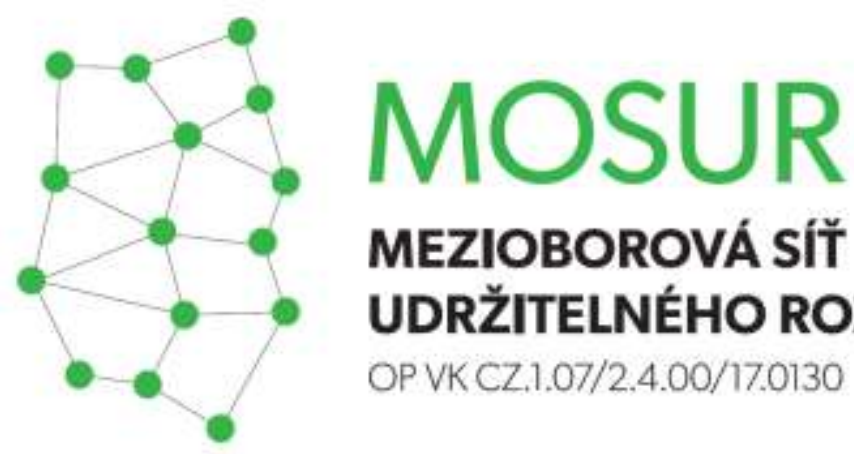

\section{MEZIOBOROVÁ SÍT}

UDRŽITELNÉHO ROZVOJE

OP VK CZ.1.07/2.4.00/17.0130
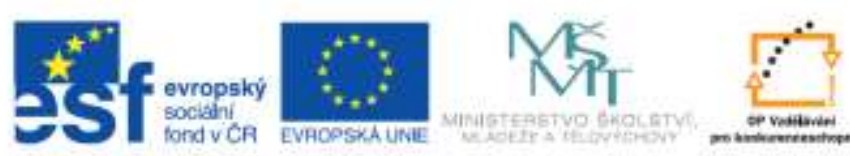

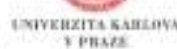

INVESTICE DO ROZVOJE VZDELAVANI 